\title{
GENETIC OF Panulirus versicolor LOBSTER IN CENDRAWASIH BAY PAPUA AND LOMBOK WATERS WEST NUSA TENGGARA
}

\author{
Bayu Pranata ${ }^{1}$, Abdul H.A. Toha ${ }^{1}$, Duaiht Kolibongso ${ }^{2}$ \\ ${ }^{1}$ Department of Fisheries, Faculty of Fisheries and Marine Sciences, \\ University of Papua, Manokwari, Indonesia. \\ ${ }^{2}$ Department of Marine Sciences, Faculty of Fisheries and Marine \\ Sciences, University of Papua, Manokwari, Indonesia \\ E-mail: b.pranata@unipa.ac.id
}

Received July 2020, Accepted September 2020

\begin{abstract}
The purpose of this study was to determine the level of diversity and genetic relationship of Panulirus versicolor lobsters in Cenderawasih Bay and Lombok waters based on the cytochrome oxidase I (COI) gene. The results showed the level of genetic diversity of the two populations was very high and generally did not differ greatly between populations. We identified 6 haplotypes for $P$. versicolor lobster populations from Cenderawasih Bay and 7 haplotypes for $P$. versicolor lobster populations from Lombok waters. Network analysis shows that several P. versicolor lobster individuals from the Cendeawasih Bay and Lombok waters had similar haplotypes. The population of Cenderawasih Bay with Lombok waters was closely related to the average genetic distance value $P$ distance 0.005 (s.d 0.001) and the results of phylogenetic tree reconstruction showed that the two populations of $P$. versicolor lobsters form a monophyletic clade (close relatives).
\end{abstract}

Keywords : Panulirus versicolor, COI, Genetic Diversity, Phylogenetic

\section{INTRODUCTION}

Lobster Panulirus versicolor of the genus Panulirus or called spiny lobster, plays a substantial role as a source of protein and becomes an important commodity for Indonesian fisheries. This lobster inhabits the shallow areas of the Indo-Western Pacific Ocean coral reefs (George, 1974), and is one of the most valuable species of all fish species on coral reefs. Indonesian Statistical Data in 2005, shows that there was an increase in lobster utilization from 2005-2012 which reached $19.23 \%$ of the total catch in all WPP (Fisheries Management Areas) in Indonesia. In the waters of Lombok it produces 78.5 tons of lobster a year worth 55.25 billion.

Spiny lobster is one of 6 lobster species captured in Indonesian waters (Tewfik et al., 2009). Catching lobsters is generally done directly in nature with target lobsters namely adult individuals and puerulus stage 
lobsters. In some countries such lobster culture has been developed in the waters of Lombok and Cenderawasih Bay, Indonesia. Lobster cultivation is done by taking seeds inside. This is economically beneficial, but if management is not carried out properly, it can lead to overfishing and result in a decrease in the stock and genetic diversity of the lobster population in the wild.

Declining of genetic diversity has become an important problem in fisheries management (Çiftci and Okumu, 2002). Genetic diversity has significance for organisms in a population. Çiftci and Okumus (2002) explain that genetic diversity is a raw material in species and populations, which makes it possible to adapt to environmental changes. Decreased genetic diversity affects the ability to adapt to changes in environmental change, reproduction, growth and development, and resistance to disease. As the results of Hedgecock and Nelson (2009), showed that the variation in the growth rate of juvenile lobster Homarus americanus, 30\% is influenced by heritability or genetic diversity.

Spiny lobster is a tropical species with a complex life cycle. The initial phase of the Panulirus lobster consists of a long pelagic larval period and is plantonic in the open sea (Tolley et al., 2005). Spiny lobster phyllosoma larvae are about 1-2 $\mathrm{mm}$ in size and the larval phase lasts for 6-7 months, before the phyllosoma larvae morph into puerulus (Phillips et al., 2006). The larval phase is long, causing the spiny lobster to have a wide spread and allows stock to occur between regions (Abdullah et al., 2014), resulting in gene flow through crossbreeding (outbreeding) between populations.

Cenderawasih Bay is geographically affected directly by oceanographic processes from the Pacific Ocean while Lombok waters are affected by oceanographic processes from the Indian Ocean and is a pathway for the release of water masses from the Pacific Ocean under the ARLINDO (Indonesian Cross Flow) to the Indian Ocean. The waters of Lombok are open geographically, so the chance of meeting or entering the lobster phyllosoma larvae from several areas in the Pacific Ocean is referred to as Cenderawasih Bay.

Currents tend to create resistance and direction from the spread of lobster phyllosoma larvae (Riginos et al., 2011). Therefore, it is important to identify the diversity and genetic structure of $P$. versicolor lobster from Cenderawasih Bay and Lombok waters. Knowledge of diversity and genetic structure is very important to understand the process of evolution, adaptation, morphology, ecology and behavior of species (Suresh et al., 2012). In addition, understanding genetic and phylogenetic links is very important for management and conservation planning because it can identify the routes of larval distribution, or barriers to spread.

Identification of genetic spiny lobsters using the $\mathrm{COI}$ gene (cytochrome oxidase $c$ subunit $I$ ) which is a protein coding region of the mitochondrial genome. The COI gene is a DNA barcode for animals. The purpose of this study is to identify diversity, genetic structure, phylogenetic and implications for the management of $P$. versicolor lobster spiny in Cenderawasih Bay and Lombok waters. 


\section{MATERIALS AND METHODS}

Spiny Lobster samples in this study came from 2 locations, namely from Cenderawasih Bay and Lombok waters. The total number of spiny lobster samples used was 20 individuals. 10 Individuals from Cenderawasih Bay and 10 Individuals from Lombok waters. The tissue used for gene analysis was the lobster foot tissue (pereiopod), the tissue was preserved with $90 \%$ alcohol.

Genomic DNA extraction from all samples using the KIT method: Genomic DNA Mini Kit Animal Tissue (GENE AID). Amplification (PCR) of the cytochrome oxidase I (COI) mitochondrial locus gene was carried out using primers LCO1490: 5'-ggtcaacaaatcataaagatattgg-3 'and HCO2198: 5'-taaacttcagggtgaccaaaaaatca-3' (Folmer et al., 1994). Amplification is carried out at the final volume of $50 \mu$ l. The PCR process includes predenaturation at $94^{\circ} \mathrm{C}$ for 3 minutes, followed by 35 cycles consisting of denaturation at $94{ }^{\circ} \mathrm{C}$ for 30 seconds, annealing at $50{ }^{\circ} \mathrm{C}$ for 30 seconds and an extension stage at $72{ }^{\circ} \mathrm{C}$ for 45 seconds. The results of the PCR were then carried out by an electrophoresis process to separate, identify and purify DNA fragments. The subsequent PCR results were observed qualitatively using $1 \%$ agarose gel electrophoresis.

DNA sequences were aligned using MEGA 6.06 software (Tamura et al., 2011). Sequence data were then matched with data available at NCBI (National Center for Biotechnology Information) genbank online (www.ncbi.nml.nih.gov) with the BLAST (Basic Local Alignment Searc Tool) method. Analysis of the diversity of nucleotides (m), haplotypes (h), polymorphic DNA, using DnaSP 5.1 (Rozas et al., 2003). Phylogenetic reconstruction using the Maximum Likehood Trees method Kimura-2 parameter model and $1000 \times$ bootstrap value using MEGA 6.06 software.

\section{RESULTS AND DISCUSSION}

\section{Genetic Diversity of $\boldsymbol{P}$. Versicolor}

Analysis of genetic diversity using DNA SP 5.10. showed the diversity of haplotypes $(\mathrm{Hd})$ and nucleotides $(\mathrm{Pi})$ in the lobster samples studied. Overall genetic diversity of spiny lobsters from Cenderawasih Bay and Lombok waters can be seen in Table 1. Categories of haplotype diversity values were $\geq 0$ to $<0.5$ low category and $>0.5$ to $\leq 1$ high category (Hobbs et al., 2013). Meanwhile, according to Nei (1987) haplotype diversity from 0.1 to 0.4 is the low category, 0.5 to 0.7 is the medium category and $0.8-2.00$ the high category. Based on this, we conclude that the genetic diversity of spiny lobster in Cenderawasih Bay and Lombok waters was in the high category. The level of genetic diversity of the two study sites showed results that did not differ greatly. 
Table 1. Genetic diversity of spiny lobster Panulirus versicolor

\begin{tabular}{lllll}
\hline No. & Location & Jumlah $(\mathbf{n})$ & Haplotipe $(\boldsymbol{H d})$ & Nukleotida $(\boldsymbol{P i})$ \\
\hline 1. & $\begin{array}{l}\text { Cenderawasih } \\
\text { Bay }\end{array}$ & 10 & 0,844 & 0,00532 \\
2. & Lombok & 10 & 0,867 & 0,00492 \\
\hline
\end{tabular}

\section{Genetik Distance and Haplotype Network}

Analysis of genetic distance between spiny lobster populations from Cenderawasih Bay and Lombok waters showed a close relationship with the average value of $P$. distance 0.005 (s.d 0.001). The genetic proximity is probably due to the lobster spiny from Cenderawasih Bay and Lombok waters having genepool.

Network calculations based on Median Joining (MJ) for the reconstruction of the evolutionary relationship between haplotypes were identified using NETWORK as shown in Figure 1. In Figure 1, the color circle represents different individual haplotypes and the size of the circle shows the relative frequency of each haplotype. Haplotypes $(\mathrm{H} 2)$ were the most dominant haplotypes (central haplotypes) found in lobster spiny populations. Long or short branches of several haplotypes describe the number of changes that occur in the DNA sequence to form a variety of haplotypes. The longer the branch formed, the more changes occur in the DNA sequence and vice versa.

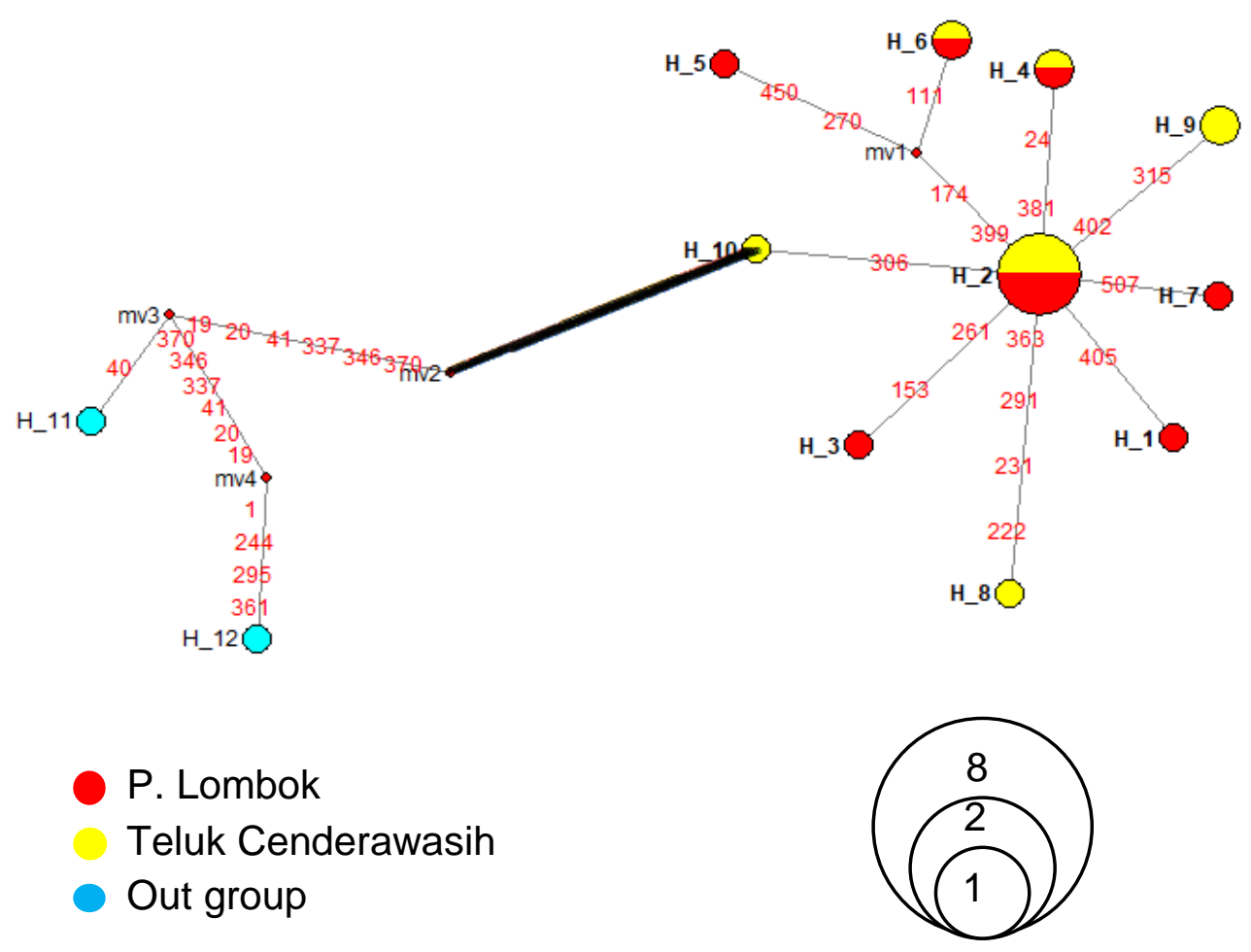

Figure 1. Spiny lobster haplotype network 
Reconstruction of the haplotype network between the spiny lobster population of Cenderawasih Bay and the waters of Lombok provides information that the two populations share the same haplotype. The results of the analysis showed that several individual spiny lobsters from Cenderawasih Bay and Lombok waters had similar haplotypes, thus failing to show a grouping (Clade) between different geographical locations.

Previous research shows the distribution of $P$. versicolor haplotypes in the Gulf of Cenderawasih and the area around the Pacific Ocean showed that all were closely related and that no sample areas were genetically isolated from each other (Pranata et al., 2018). The haplotype distribution pattern can be used as an indicator for stock identification (Senevirathna and Munasinghe 2014). There is a strong genetic structure when out groups originating from the same genus are combined with research data.

\section{Phylogenetic Spiny Lobster $\boldsymbol{P}$. versicolor}

Phylogenetic analysis was carried out to determine the relationship of spiny lobster from both locations using the Maximum Likehood Trees (ML) method with Kimura 2-Parameter. Significantly $P$. versicolor lobsters from Cenderwasaih Bay and Lombok Island form monophyletic clades and no genetic structure was formed between populations (Figure 2).

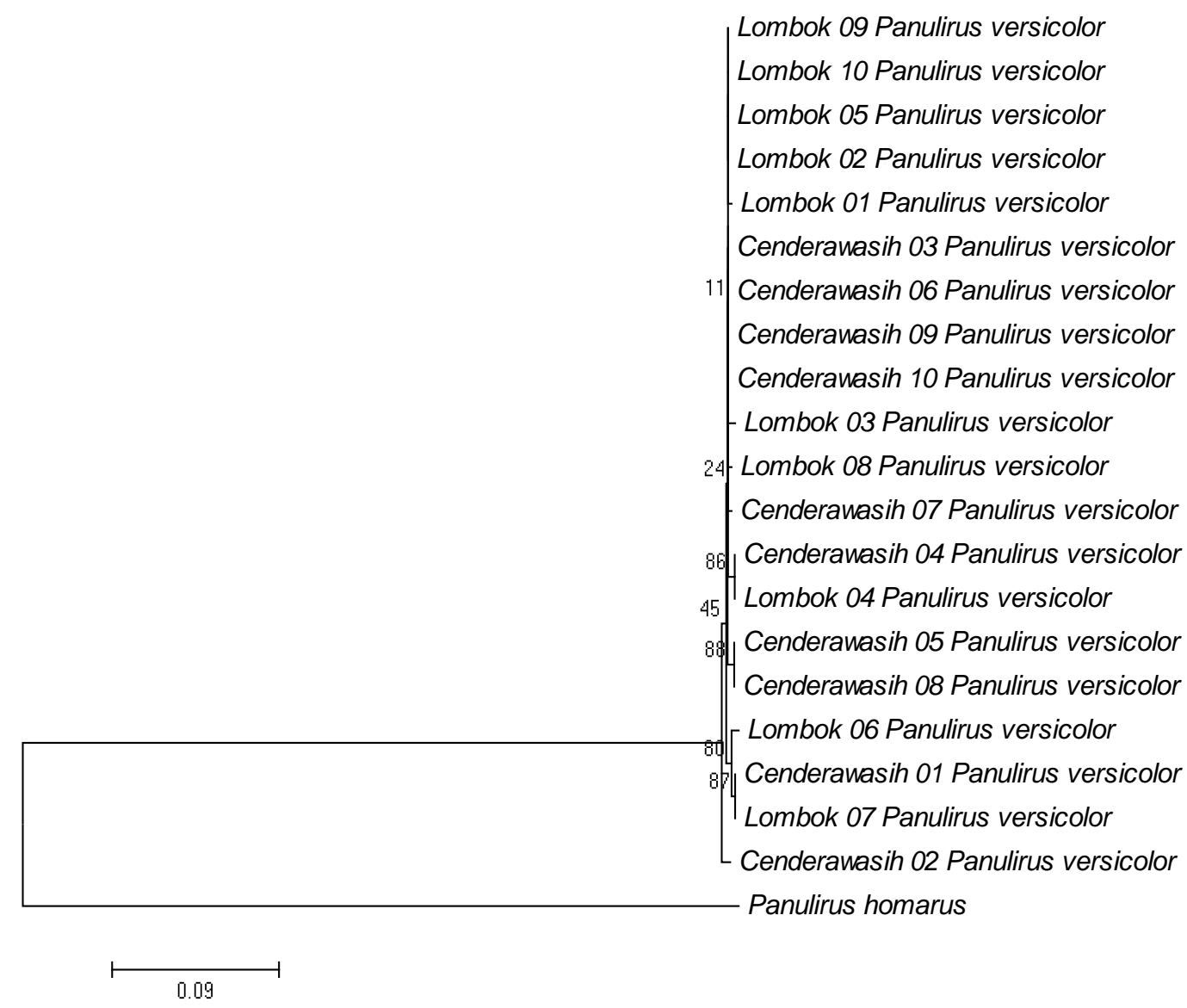

Figure 2. Phylogenetic Spiny Lobster Panulirus versicolor 
Similar results were found by Chow et al. (2011), in which the phylogenetic tree population of $P$. penicillatus lobster from the Central Pacific formed a monophyletic clade with a population based on the Western Pacific. In addition, Abdullah et al. (2014) also found no genetic structure in the phylogenetic tree of $P$. penicillatus lobster populations from Aceh, Java, Maldives and Madagascar. Spiny lobster P. versicolor of Cenderawsih Bay form a monophyletic clade with $P$. versicolor in other part of the western Pacific Ocean based on the reconstruction of phylogenetic trees (Pranata et al., 2018). The wide distribution makes it impossible to identify the genetic structure of the lobster phylogenetic tree between several observed populations. As expected, outgroups of the same genus form different groups from the observed species.

\section{Resource Management}

The genetic diversity of spiny lobster from both populations was still relatively high, giving an indication that the population had a good survival rate. This information is important for the development of aquaculture for these species, as Yuniarti et al. (2009) explains that the improvement of seed quality is genetically determined by the diversity and genetic structure of the parent. The results of this study indicate that the population of Lombok waters was genetically superior even though the level of genetic diversity of the two locations did not differ greatly. The waters of Lombok were more likely to receive gene flow or stock supply from various regions in the Indian Ocean and the Pacific, so that higher variations occur in the region. In addition, no genetic structure occured between the two locations and several locations in the Pacific Ocean and Indian Ocean. This species has a wide distribution. This species may experience a local decline due to capture, but has no impact on the global population. At present, management strategies for these species are generally based on the precautionary principle (Fisch, 2007).

High economic value and utilization patterns as a reason for the importance of genetic management and conservation of lobster resources are carried out. Lobster has a broad distribution pattern so that there is a need for regulations for the management and conservation of these resources such as determining the minimum size limit and the amount of catch both between regions and countries. Determination of the minimum threshold is important to ensure supply of stock and gene flow that occurs between populations because some populations can obtain new genes, through larval migration or mutation processes, population size and crossbreeding. While limiting the amount of catch to maintain the stability of the natural population. 


\section{CONCLUSION}

The genetic diversity of spiny lobsters from Cenderawasih Bay and Lombok waters was very high. There was no genetic structure that occurs in the two study sites that indicate connectivity and flow. The results of phylogenetic tree reconstruction showed that the spiny lobster population from both locations formed a monophyletic clade (closely related). Need further research to answer whether connectivity occurs directly or both populations have the same parent origin.

\section{ACKNOWLEDGEMENT}

We would like to thank the Genetics Laboratory of the University of Papua for its assistance in facilitating this research, the Cendrawasih Bay National Park Authority for its assistance in issuing research permits in the Cendrawasih Bay National Park.

\section{REFERENCES}

Abdullah, M.F., Alimuddin, Muththalib, M., Salama, A.J., Imai, H. 2014. Genetic isolation among the Northwestern, Southwestern and Central-Eastern Indian Ocean populations of the pronghorn spiny lobster Panulirus penicillatus. International Journal of Molecular Sciences, 15: 9242.9254.

Çiftci, Y., Okumu, I. 2002. Fish population genetics and applications of molecular markers to fisheries and aquaculture: I-basic principles of fish population genetics. Turkish Journal of Fisheries and Aquatic Sciences, 2: 145.155.

Chow, S., Jeff, A., Miyake, Y., Konishi, K., Okazaki, M., Suzuki, N., Abdullah, M.F., Imai, H., Wakabayasi, T. and Sakai, M. 2011. Genetic isolation between western and eastern Pacific populations of pronghorn spiny lobster Panulirus penicillatus. Journal PLoS ONE, 6: e29280.

Folmer, O., Black, M., Hoeh, W., Lutz, R., Vrijenhoek, R. 1994. DNA primers for amplification of mitochondrial cytochrome c oxidase subunit I from diverse metazoan invertebrates. Molecular Marine Biology and Biotechnology, 3(5): 294.299.

Fisch, A.J. 2007. Short and long-term movements of painted lobster (Panulirus versicolor) on a coral reef at Northwest Island, Australia. Coral Reefs, 26: 311.317. 
George, R.W. 1974. Coral reefs and rock lobster ecology in the Indo-West Pacific region. Proceedings of the Second International Coral Reef Symposium. Vol. 1. The Great Barrier Reef Committee, Brisbane, Australia: 321.326.

Hedgecock, D., Nelson, K. 2009. Components of growth rate variation among laboratory cultured lobsters (Homarus). Journal of the World Aquaculture Society, 9: 125.137.

Hobbs, J.P., Lynne, V.H., Dean, R.J., Geoffrey, P.J., Philip, L.M. 2013. High genetic diversity in geographically remote populations of endemic and widespread coral reef Angelfish. Diversity, 5:39-50.

Nei, M. 1987. Moleculer Evolutionary Genetics. New York. Columbia University. Press. New York.

Phillips, B.F., Melville-Smith, R., Kay, M.C., Vega-Velázquez. 2006. Panulirus species, in: Phillips, B.F. (Eds.), Lobsters: Biology, Management, Aquaculture and Fisheries. Blackwell Publishing., London: 289.315.

Pranata, B., Fadjar, M., Iranawati, F., and Toha, A.H and Jeni. 2018. Phylogeny of the spiny lobster Panulirus versicolor in Cenderawasih Bay, Papua, Indonesia. AACL Bioflux, 11 (4): 1015-1024.

Rozas, J., Sanchez-Del Barrio, J.C., Messeguer., Rozas, X.R. 2003. DnaSP, DNA polymorphism analyses by the coalescent and other methods. Bioinformatics, 19: 2496.2497.

Riginos, C., Douglas, K.E., Jin, Y., Shanahan, D.F., Treml, E.A. 2011. Effects of geography and life history traits on genetic differentiation in benthic marine fishes. Ecography. 34: 566.575.

Suresh, P., Sasireka, G., Karthikeyan, K.A.M. 2012. Molecular insights into the phylogenetics of spiny lobsters of Gulf of Mannar marine biosphere reserve based on $28 \mathrm{~S}$ rDNA. Indian Journal of Biotechnology, 11:182-186.

Senevirathna, J., Munasinghe, D. 2014. Genetic diversity and population structure of Panulirus homarus Populations of Southern Sri Langka and South India revealed by the Mitochondrial COI gene region. International Conference on Food, Biological and Medical Sciences, Bangkok, Thailand.

Tamura, K., Peterson, D., Peterson, N., Stecher, G., Nei, M., Kumar, S. 2011. MEGA5: Molecular evolutionary genetics analysis using maximum likehood, evolutionary distance and maximum parsimony method. Moleculer Biology Evolution, 28(10): 2731.2739. 
Tolley, K. A., Groeneveld, J. C., Gopal, K., Matthee, C.A. 2005. Mitochondrial DNA panmixia in spiny lobster Palinurus gilchristi suggests a population expansion. Marine Ecology Progress Series, 297:225-231.

Tewfik, A., Mills D and Adhuri, D. 2009. Spiny lobster aquaculture in the Asia-Pacific region. Australian Centre for International Agricultural Research: 27.34.

Yuniarti, A., Kilawati, Y dan Hariati. (2009). Kajian heterogenitas genetik abalon (Haliotis asinina) di perairan Indonesia melalui metode restriction fragment length polymorphism (RFLP) mtDNA. Laporan Penelitian Hibah Penelitian Strategis Nasional. Universitas Brawijaya, Malang. 